Article

\title{
Synthesis, Characterization and Antibacterial Activity of Novel 1,3-Diethyl-1,3-bis(4-nitrophenyl)urea and Its Metal(II) Complexes
}

\author{
Hoda Pasdar*, Bahare Hedayati Saghavaz, Naser Foroughifar and Mehran Davallo \\ Department of Chemistry, North Tehran Branch, Islamic Azad University, Tehran 1651153311, Iran; \\ bahare.hedayati67@gmail.com (B.H.S.); nforoughifar@gmail.com (N.F.); m_davallo@yahoo.com (M.D.) \\ * Correspondence: H_pasdar@iau-tnb.ac.ir; Tel.: +98-912-175-4903
}

Received: 28 October 2017; Accepted: 27 November 2017; Published: 2 December 2017

\begin{abstract}
A bioactive ligand and its dinuclear metal(II) complexes were synthesized and characterized by Fourier-transform infrared spectroscopy (FT-IR), ultraviolet-visible (UV-Visible), nuclear magnetic resonance $\left({ }^{1} \mathrm{H}-\mathrm{NMR}\right)$, mass spectroscopy and molar conductance measurements. The ligand has been crystalized in the monoclinic system with a P21/c space group. The biological activities of metal complexes were evaluated using disc diffusion and broth dilution methods. In vitro antibacterial activities of the ligand and their metal complexes were examined against two Gram-positive bacteria (Bacillus subtilis and Staphylococcus aureus) and two Gram-negative bacteria (Escherichia coli and Serratia marcescens) and compared to the standard drugs. It was found that metal complexes displayed much higher antibacterial activities and better inhibitory effects than that of the ligand and standard drugs. Among these complexes, the compound having Zn-metal showed greater antibacterial activity against all four tested bacteria and was more effective against Serratia marcescens with the zone inhibition diameter of $26 \mathrm{~mm}$ and MIC value of $31.25 \mu \mathrm{g} / \mathrm{mL}$.
\end{abstract}

Keywords: dinuclear metal(II) complexes; monoclinic system; symmetrical urea; antibacterial activity; disc diffusion; broth dilution

\section{Introduction}

In the past few decades, due to the changes in human habits and climate changes, bacterial infections have been a major cause of illness or death [1]. Antibiotics are essential to treat infections caused by bacteria. However, their overuse and misuse by humans have been linked to bacteria resistance, which is a severe public health problem [2]. To overcome this serious medical problem, the discovery of new types of antibiotics or the expansion of existing drugs is a very important and challenging issue [3]. Therefore, in recent years, research has been focused on developing new drugs, which may act through structural changes, to solve the problem of bacterial drug resistant [4].

Linkage isomerism is of major interest in the field of inorganic chemistry can be used to develop new compounds with potential pharmaceutical applications in the field of biomedicine [5-7]. Linkage isomerism occurs when an ambidentate ligand (e.g., $\mathrm{NO}_{2}, \mathrm{SCN}, \mathrm{CNO}$, etc.) binds to the metal center [8-10]. Nitro-nitrito metal complexes can be regarded as good examples of linkage isomerism, which was first described by Jørgensen and further developed through the syntheses of $\left[\left(\mathrm{NH}_{3}\right)_{5} \mathrm{CoNO}_{2}\right] \mathrm{Cl}_{2}$ and [( $\left.\left.\left.\mathrm{NH}_{3}\right)_{5} \mathrm{CoONO}\right]\right] \mathrm{Cl}_{2}$ complexes by Werner [11]. It must be noted that the $\mathrm{NO}_{2}$ group can be coordinated to the metal atom in different ways such as nitro (via the nitrogen), nitrito (via oxygen), chelating via both oxygens (nitrito-O, $\mathrm{O}^{\prime}$ ), and bridging nitro, usually via nitrogen and oxygen atoms. It has been shown that the coordination mode of nitrite ion depends on its nature and the stereochemical environment which surrounds the metal ion [12-15]. Apart from the wide range 
of $\mathrm{NO}_{2}$ binding modes in mononuclear metal complexes, their potential tendency to act as bidentate ligand must be mentioned [16]. Various coordination modes of $\mathrm{NO}_{2}$ group are shown in Figure 1.<smiles>[Y4]ON([Y3])O[V]</smiles><smiles>[Y3]N1O[Al]O1</smiles><smiles>[Y9][14CH2]NO</smiles><smiles></smiles><smiles>[Y4]N(O)O</smiles><smiles>N1O[Al]O1</smiles><smiles>ON1[C@H]2ON21</smiles><smiles>[Y]ONO[W]</smiles><smiles>[Y9]ONO</smiles>

$\mathrm{M}=$ metal

Figure 1. Different coordination modes of $\mathrm{NO}_{2}$ group.

Coordination chemistry of $\mathrm{NO}_{2}$ complexes is very attractive due to the significant role they play in different biosystems [17]. It appears that the biological function of nitrite ion $\left(\mathrm{NO}_{2}\right)$ is contingent upon the nitrite reaction with metalloproteins which results in greater diversity of binding modes of the nitrite ligand and therefore can provide several reaction pathways that can lead to numerous biological species [18]. It has been reported that the presence of nitrite ion in mammalian biological systems at micromolar concentrations can play a crucial role by serving as a biological reserve of the bioregulatory agent for nitric oxide [19]. It has also been found that various metal complexes synthesized from the same ligand may display diverse biological properties [20]. The present study reports on the synthesis, characterization and antibacterial activities of the ligand and its metal complexes.

\section{Results and Discussion}

\subsection{Characterization of Ligand}

The symmetrical $\mathrm{NO}_{2}$-ligand (L) was synthesized by the reaction of n-Ethyl-4-nitro aniline and phosgene with a good yield (92\%). A perspective view with the atom labeling of the ligand is given in Figure 2. In the $\mathrm{X}$-ray crystallographic analysis, each unsymmetrical unit cell consists of two ligands (Figure 3).

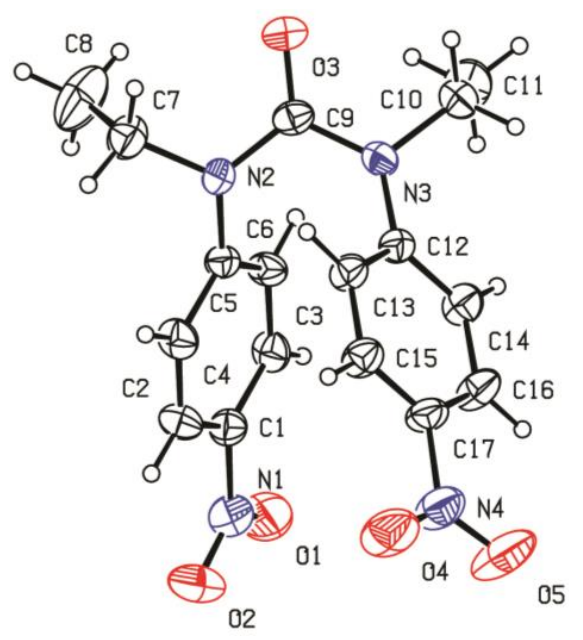

Figure 2. Crystal structure of ligand. 

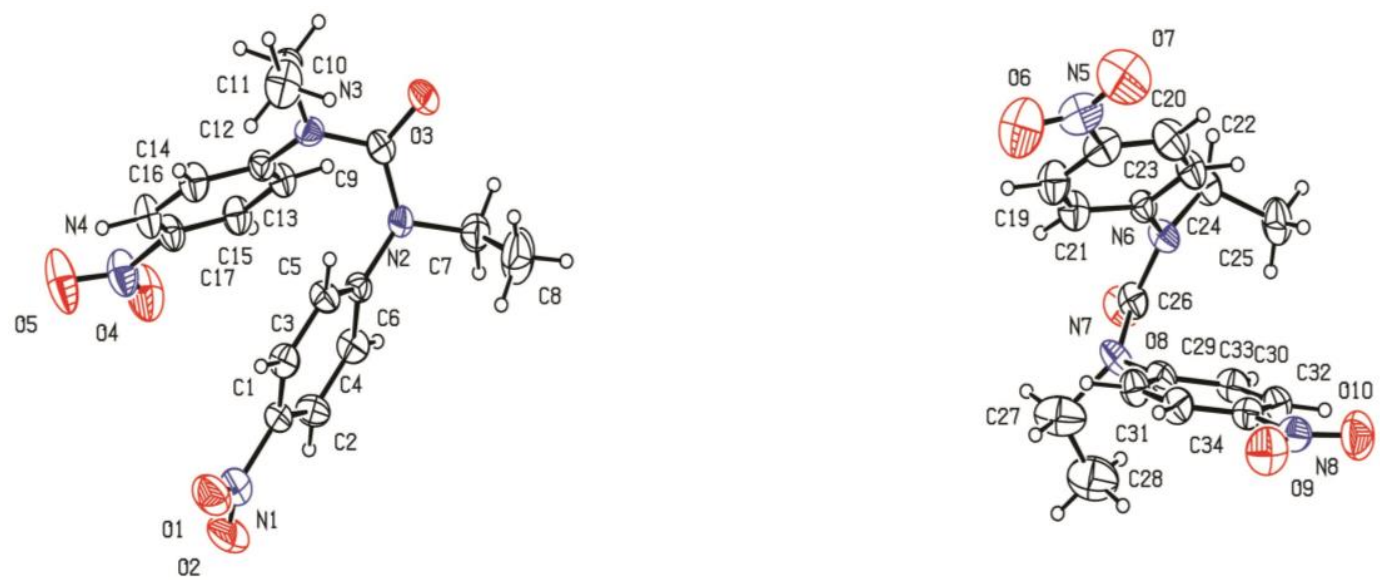

Figure 3. Unit cell of $\mathrm{C}_{17} \mathrm{H}_{18} \mathrm{~N}_{4} \mathrm{O}_{5}$.

Selected bond lengths and angles of the ligand (L) are given in Table 1.

Table 1. Selected bond lengths ( $\mathrm{A})$ and bond angles $\left(^{\circ}\right)$.

\begin{tabular}{cccc}
\hline \multicolumn{2}{c}{ Bond (̊̊) } & \multicolumn{2}{c}{ Angle $\left(^{\circ}\right)$} \\
\hline $\mathrm{O}(1)-\mathrm{N}(1)$ & $1.223(4)$ & $\mathrm{O}(1)-\mathrm{N}(1)-\mathrm{O}(2)$ & $123.7(4)$ \\
$\mathrm{O}(2)-\mathrm{N}(1)$ & $1.223(4)$ & $\mathrm{O}(1)-\mathrm{N}(1)-\mathrm{C}(1)$ & $118.2(4)$ \\
$\mathrm{O}(3)-\mathrm{C}(9)$ & $1.222(4)$ & $\mathrm{O}(2)-\mathrm{N}(1)-\mathrm{C}(1)$ & $118.0(4)$ \\
$\mathrm{O}(4)-\mathrm{N}(4)$ & $1.204(4)$ & $\mathrm{C}(9)-\mathrm{N}(2)-\mathrm{C}(6)$ & $122.8(3)$ \\
$\mathrm{O}(5)-\mathrm{N}(4)$ & $1.214(4)$ & $\mathrm{C}(9)-\mathrm{N}(2)-\mathrm{C}(7)$ & $116.6(3)$ \\
$\mathrm{O}(6)-\mathrm{N}(5)$ & $1.213(4)$ & $\mathrm{C}(6)-\mathrm{N}(2)-\mathrm{C}(7)$ & $118.6(3)$ \\
$\mathrm{O}(7)-\mathrm{N}(5)$ & $1.207(4)$ & $\mathrm{C}(9)-\mathrm{N}(3)-\mathrm{C}(12)$ & $123.4(3)$ \\
$\mathrm{O}(8)-\mathrm{C}(26)$ & $1.213(4)$ & $\mathrm{C}(9)-\mathrm{N}(3)-\mathrm{C}(10)$ & $116.0(3)$ \\
$\mathrm{O}(9)-\mathrm{N}(8)$ & $1.222(4)$ & $\mathrm{C}(12)-\mathrm{N}(3)-\mathrm{C}(10)$ & $119.5(3)$ \\
$\mathrm{O}(10)-\mathrm{N}(8)$ & $1.221(4)$ & $\mathrm{O}(4)-\mathrm{N}(4)-\mathrm{O}(5)$ & $123.0(4)$ \\
$\mathrm{N}(1)-\mathrm{C}(1)$ & $1.469(5)$ & $\mathrm{O}(4)-\mathrm{N}(4)-\mathrm{C}(17)$ & $118.7(4)$ \\
$\mathrm{N}(2)-\mathrm{C}(9)$ & $1.383(4)$ & $\mathrm{O}(5)-\mathrm{N}(4)-\mathrm{C}(17)$ & $118.3(4)$ \\
$\mathrm{N}(2)-\mathrm{C}(6)$ & $1.413(4)$ & $\mathrm{O}(7)-\mathrm{N}(5)-\mathrm{O}(6)$ & $125.4(5)$ \\
$\mathrm{N}(2)-\mathrm{C}(7)$ & $1.470(4)$ & $\mathrm{O}(7)-\mathrm{N}(5)-\mathrm{C}(18)$ & $117.1(5)$ \\
\hline
\end{tabular}

In the ${ }^{1} \mathrm{H}-\mathrm{NMR}$ spectrum of the ligand, doublet peaks appear at $7.92(\mathrm{~J}=8 \mathrm{~Hz})$ and $7.17(\mathrm{~J}=8 \mathrm{~Hz})$ ppm, and are attributed to the aromatic protons. The $\mathrm{CH}_{2}$ and $\mathrm{CH}_{3}$ groups appear at $3.74(\mathrm{~J}=6.75 \mathrm{~Hz})$ and $1.093(\mathrm{~J}=12 \mathrm{~Hz}) \mathrm{ppm}$, respectively, indicated the ethyl group of the ligand.

\subsection{Characterization of Metal Complexes}

Physical properties of the synthesized compounds are presented in Table 2. The $\mathrm{NO}_{2}$ group of ligand can bind to the metal atoms in a variety of different ways. As an ambidentate ligand, it can coordinate via nitrogen (nitro) or via oxygen (nitrito), and, as a bidentate ligand, it can coordinate via the two oxygens (nitrito- $\mathrm{O}, \mathrm{O}^{\prime}$ ), and via one nitrogen and one oxygen or via a singlet oxygen atom. The synthetized metal complexes were obtained in moderate yield (50-83\%), as shown in Table 2. In all experiments, ligand and metal salts were reacted (molar ratio 1:2) in ethanol solution under reflux condition. The prepared metal complexes were colored; stable; insoluble in methanol, ethanol, acetonitrile and chloroform; and well soluble in DMSO and DMF. 
Table 2. Physical properties of Ligand (L) and its metal complexes.

\begin{tabular}{|c|c|c|c|c|c|}
\hline Compounds & M.W. (g/mol) & Yield (\%) & Color & $\begin{array}{l}\text { Conductivity } \\
\Omega \mathrm{cm}^{2} \mathrm{~mol}^{-1}\end{array}$ & M.P. $\left({ }^{\circ} \mathrm{C}\right)$ \\
\hline $\mathrm{L}$ & 358 & 92 & Colorless & - & 149-151 \\
\hline $\mathrm{CuL}$ & 645 & 87 & Dark green & 12 & 149-151 \\
\hline CoL & 636 & 83 & Pale blue & 8 & $242-244$ \\
\hline $\mathrm{NiL}$ & 636 & 70 & Pale green & 10 & $240-242$ \\
\hline PtL & 910 & 50 & Dark brown & 14 & $>300$ \\
\hline PdL & 730 & 75 & Black & 12 & $>300$ \\
\hline $\mathrm{CdL}$ & 743 & 78 & Cream & 20 & $282-284$ \\
\hline $\mathrm{ZnL}$ & 648 & 80 & White & 14 & $250-253$ \\
\hline
\end{tabular}

Metal complexes were characterized by Fourier-transform infrared spectroscopy (FT-IR), ultraviolet-visible (UV-Visible), and mass spectroscopy. The proposed structure of metal complexes is shown in Figure 4.

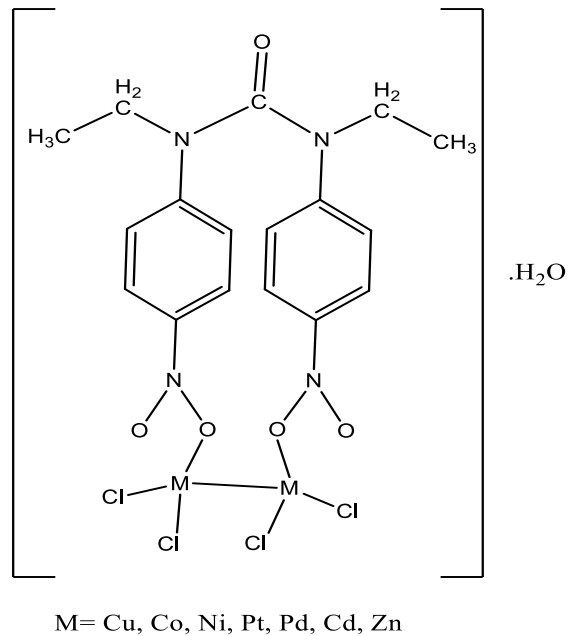

Figure 4. Proposed structure of metal complexes.

The molar conductivity of metal complexes was measured using the conductometric method. The molar conductivity of metal complexes was calculated using Equation (1):

$$
\Lambda_{\mathrm{m}}=\frac{\kappa}{\mathrm{C}}
$$

where $\kappa$ the measured conductivity and $\mathrm{C}$ is the concentration of the solutions. The molar conductance values of all the complexes were in the range 8-20 $\Omega^{-1} \mathrm{~cm}^{2} \mathrm{~mol}^{-1}$ which indicated these complexes were non-electrolytes.

Important FTIR data are summarized in Table 3. As can be observed in Table 3, the C-H (aromatic) and C-H (aliphatic) bands for the ligand appear at $3109 \mathrm{~cm}^{-1}$ and $2975 \mathrm{~cm}^{-1}$, respectively. However, for the metal complexes, these bands were shifted to lower values in comparison to the parent ligand. The bands in the range of $1509-1591 \mathrm{~cm}^{-1}$ and $1309-1495 \mathrm{~cm}^{-1}$ correspond to the $\mathrm{NO}_{2}$ group of the ligand. The band observed at $1668 \mathrm{~cm}^{-1}$ is related to $\mathrm{C}=\mathrm{O}$ stretching of the ligand. All complexes showed a characteristic band in the range of $510-600 \mathrm{~cm}^{-1}$ that is believed to be predominantly due to the metal-oxygen stretching. These results confirmed the nitrito isomer formation. The appearance of a broad peak in the range of $3442-3332 \mathrm{~cm}^{-1}$ indicated the presence of $\mathrm{H}_{2} \mathrm{O}$ in the structure of all the complexes. 
Table 3. The Fourier-transform infrared (FTIR) spectroscopy data of ligand (L) and its metal complexes.

\begin{tabular}{cccccccc}
\hline Compounds & $\mathbf{( C - H ) a r o m a t i c}$ & $\mathbf{( C - H ) a l i p h a t i c}$ & $\left.\mathbf{( N O}_{\mathbf{2}}\right)$ & $\mathbf{( N O}_{\mathbf{2}} \mathbf{)}$ & $\mathbf{( C = O )}$ & $\mathbf{( O H ) w a t e r}$ & $\mathbf{( M - O )}$ \\
\hline L & 3109 & 2975 & 1533 & 1373 & 1668 & - & - \\
CuL & 2996 & 2912 & 1592 & 1339 & 1663 & 3442 & 510 \\
CoL & 2996 & 2912 & 1592 & 1311 & 1661 & 3439 & 600 \\
NiL & 2996 & 2912 & 1592 & 1339 & 1661 & 3432 & 600 \\
PtL & 2996 & 2913 & 1437 & 1384 & 1657 & 3434 & 550 \\
PdL & 2996 & 2912 & 1592 & 1339 & 1661 & 3438 & 600 \\
CdL & 2996 & 2912 & 137 & 1311 & 1661 & 3435 & 550 \\
ZnL & 2996 & 2912 & 1437 & 1312 & 1661 & 3435 & 510 \\
\hline
\end{tabular}

The electronic absorption spectra of the ligand and its metal complexes were recorded in DMSO solution and the data obtained are given in Table 4. The ligand showed two peaks at 260 and $340 \mathrm{~nm}$, which are attributed to the $\Pi \rightarrow \Pi^{*}$ and $\Pi \rightarrow \Pi^{*}$ transitions, respectively. For all complexes, except for $\mathrm{Cu}, \mathrm{Co}$ and $\mathrm{Ni}$, strong peaks of these transitions are present between 250 and $350 \mathrm{~nm}$ (for Cd complex; between 245 and $295 \mathrm{~nm}$ for Zn complex; between 270 and $350 \mathrm{~nm}$ for Pd complex; and between 260 and $350 \mathrm{~nm}$ for Pt complex). For Cu, Co and Ni complexes, an absorption band at 320, 350 and $295 \mathrm{~nm}$ is assigned to the $\Pi \rightarrow \Pi^{*}$ transitions, respectively. For $\mathrm{Zn}$ and Cd complexes, having $\mathrm{d}^{10}$ electron configuration, $\mathrm{d}-\mathrm{d}$ transitions were not observed for these complexes. The absorption bands at $490 \mathrm{~nm}$ for $\mathrm{Cu}$, at 600 and $700 \mathrm{~nm}$ for $\mathrm{Co}$, a very weak low-intensity at $510 \mathrm{~nm}$ for Pd, at $410 \mathrm{~nm}$ for Ni, and at $560 \mathrm{~nm}$ for Pt are associated with the $\mathrm{d}-\mathrm{d}$ transitions of the metal atoms.

Table 4. Electronic spectra data of ligand (L) and its metal complexes.

\begin{tabular}{ccc}
\hline Compounds & $\lambda_{\text {Max }}(\mathbf{n m})$ & d-d Transitions \\
\hline $\mathrm{L}$ & 260,340 & - \\
$\mathrm{CuL}$ & 320,490 & $2 \mathrm{~B}_{1} \rightarrow 2 \mathrm{~A}_{1}$ \\
$\mathrm{CoL}$ & $350,600,700$ & $4 \mathrm{~A}_{1} \rightarrow 4 \mathrm{~B}_{1}$ \\
$\mathrm{NiL}$ & 295,410 & $4 \mathrm{~A}_{1} \rightarrow 4 \mathrm{~B}_{2}$ \\
$\mathrm{PtL}$ & $280,350,560$ & $3 \mathrm{~B}_{1} \rightarrow 3 \mathrm{~A}_{2}$ \\
PdL & $260,350,510$ & $3 \mathrm{~B}_{1} \rightarrow 3 \mathrm{~A}_{1}$ \\
$\mathrm{CdL}$ & 295 & $3 \mathrm{~B}_{1} \rightarrow 3 \mathrm{~A}_{1}$ \\
$\mathrm{ZnL}$ & 270,350 & - \\
\hline
\end{tabular}

The Mass spectra of the synthesized compounds confirmed the proposed structures. The molecular ion peak for the $\mathrm{Cu}(\mathrm{II}), \mathrm{Ni}(\mathrm{II}) \mathrm{Co}(\mathrm{II}), \mathrm{Pd}(\mathrm{II}), \mathrm{Cd}(\mathrm{II})$ and $\mathrm{Zn}(\mathrm{II})$ complexes observed at $m / z=645,636,636,730,742$ and 648 , respectively, are equal to the molecular weight of these complexes. The other peaks in the mass spectrum are attributed to the fragmentation of complex inside the molecule. The fragmentation pattern of the Cu complex is shown in Figure 5.

\subsection{Antibacterial Activity}

The in vitro antibacterial activities of the ligand, its metal complexes and standard antibiotic drugs were investigated using two Gram-positive bacteria (Bacillus subtilis and Staphylococcus aureus) and two Gram-negative bacteria (Escherichia coli and Serratia marcescens) by applying the disc diffusion and broth microdilution methods. The antibacterial activities of the ligand and all the complexes were compared to standard drugs (tetracycline and amikacin). The evaluation of antibacterial effect, conducted by measuring the diameter of growth inhibition, is shown in Figure 6, and the determination of minimum inhibitory concentration (MIC) is listed in Table 5. In general, the metal complexes displayed better inhibitory effect when compared to the ligand against all tested bacteria strains with zone inhibition in the range of 8-26 mm. Among all of the metal complexes, the compound with $\mathrm{Zn}$ transition metal showed highest antibacterial activities with the zone inhibition diameter ranging from 16 to 
$26 \mathrm{~mm}$ against both Gram-positive and Gram-negative bacteria strains, compared to the standard antibacterial drugs with the zone inhibition diameter ranging from 9 to $21 \mathrm{~mm}$, as is evident in Figure 6. From the antibacterial results listed in Table 5, it can be seen that the ligand, its metal complexes and standard drugs (tetracycline and amikacin) showed different inhibition activities against various kinds of bacteria. Antibacterial activity of ligand against Bacillus subtilis showed less effectiveness with MIC value of $1000 \mu \mathrm{g} / \mathrm{mL}$, whereas, against Staphylococcus aureus, Escherichia coli, and Serratia marcescens bacteria, showed better inhibition activity with similar MIC value of $500 \mu \mathrm{g} / \mathrm{mL}$. Antibacterial activities of the seven kinds of complexes showed that majority of these complexes had effective activities against the bacteria strains. In general, the MIC of these complexes was better than that of the ligand and standard drugs. This phenomenon can be explained based on Tweedy's chelation [21,22]. The chelation reduces the polarity of metal cation to some extent due to the overlap of the ligand orbital and partial sharing of the positive charge of the metal ion. The chelation increases the delocalization of p-electrons over the whole chelate ring and enhances the lipophilicity of the complexes which, in turn, increases the penetration of the complexes into lipid membranes, and results in blockage of metal sites in the enzymes of the microorganisms. In addition, metal complexes hinder the respiration process of the cell and, block the synthesis of proteins and prevent further growth of the organism. The highest inhibition activity against Serratia marcescens bacteria was observed for Zn-metal complex with MIC value of $31.25 \mu \mathrm{g} / \mathrm{mL}$, followed by Pd-metal complex with MIC value of $62.5 \mu \mathrm{g} / \mathrm{mL}$, which were 16-fold and 8-fold higher than the respective ligand. The MIC value for Zn-metal complex suggested that this compound had much stronger antibacterial activities (Table 5). It is evident from Table 5 that the changes in different metal complexes led to the changes of the activities against the used pathogenic strains. For metal complexes, the antibacterial activities against Bacillus subtilis increased in the order: $\mathrm{Zn}=\mathrm{Cd}=\mathrm{Pd}>\mathrm{Pt}=\mathrm{Ni}=\mathrm{Co}=\mathrm{Cu}$. For metal complexes, the antibacterial activities against Escherichia coli increased in the order: $\mathrm{Zn}=\mathrm{Cd}=\mathrm{Pd}>\mathrm{Pt}=\mathrm{Co}=\mathrm{Cu}>$ Ni. For metal complexes, the antibacterial activities against Serratia marcescens increased in the order: $\mathrm{Zn}>\mathrm{Pd}>\mathrm{Cd}=\mathrm{Pt}=\mathrm{Co}=\mathrm{Cu}>\mathrm{Ni}$.

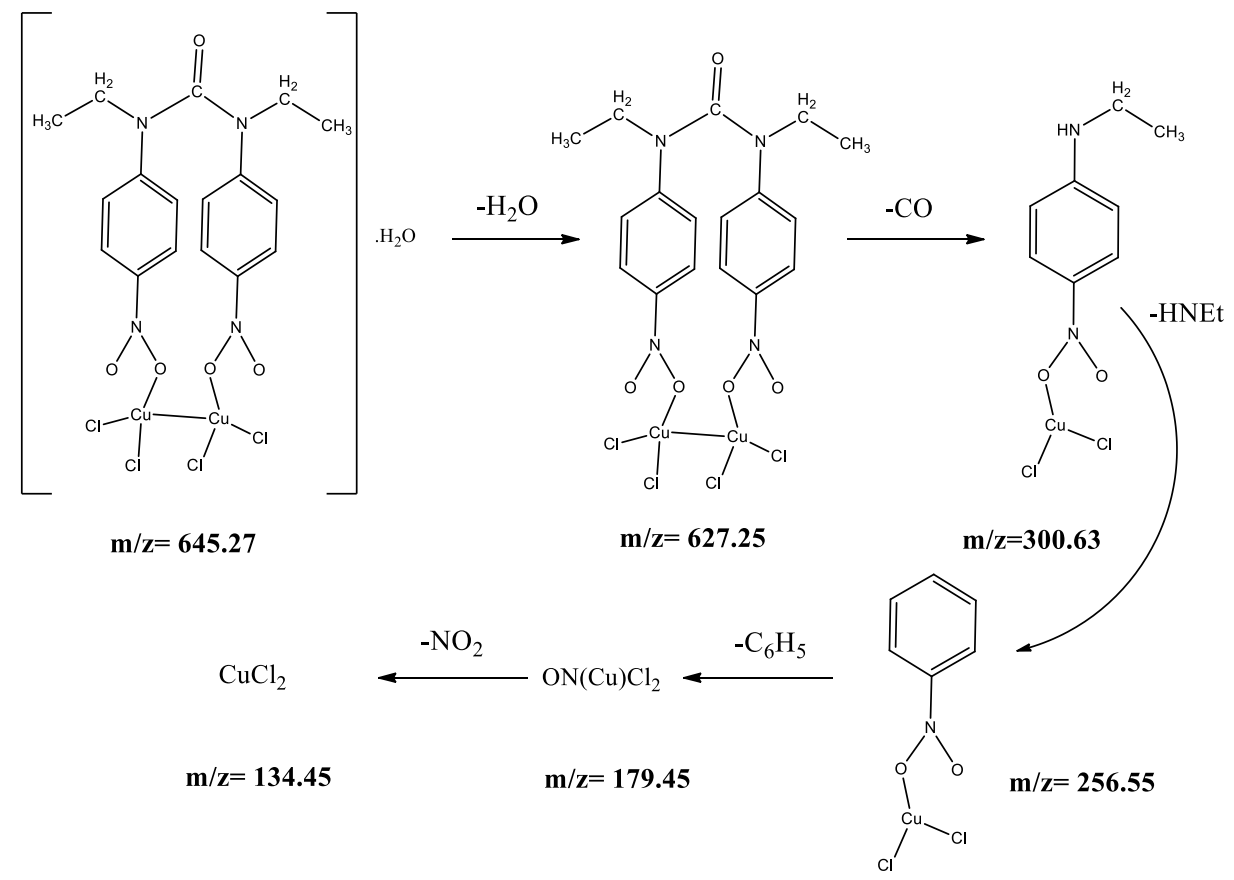

Figure 5. Mass fragmentation pattern of the CuL complex. 


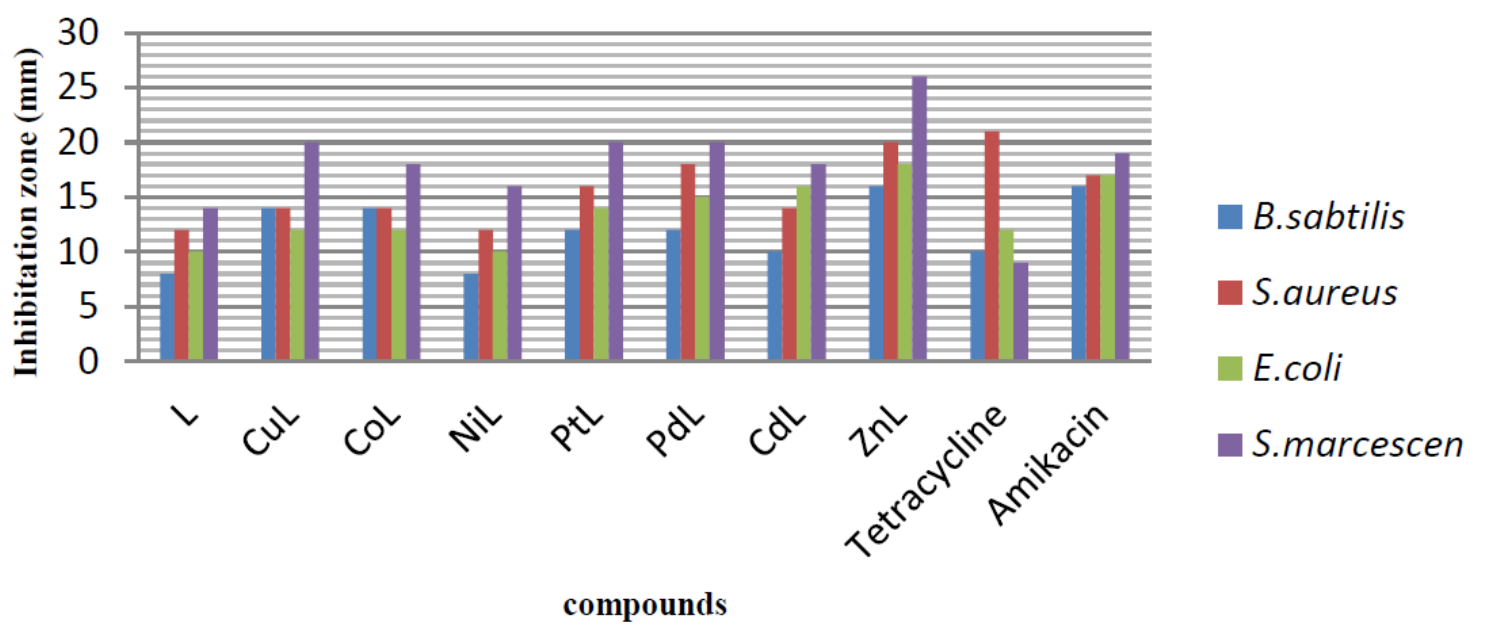

Figure 6. Graphical presentation of antibacterial activity as inhibition zone diameters ( $\mathrm{mm})$ of ligand (L) and its metal complexes against pathogenic strains based on disc diffusion method.

Table 5. Minimal inhibitory concentrations $(\mu \mathrm{g} / \mathrm{mL})$ of ligand $(\mathrm{L})$ and their metal complexes against pathogenic strains based on broth micro-dilution method.

\begin{tabular}{ccccc}
\hline \multirow{2}{*}{ Compounds } & \multicolumn{2}{c}{ G(+) } & \multicolumn{2}{c}{ G(-) } \\
\cline { 2 - 5 } & B. subtilis & S. aureus & E. coli & S. marcescens \\
\hline L & 1000 & 500 & 500 & 500 \\
CuL & 250 & 250 & 250 & 125 \\
CoL & 250 & 250 & 250 & 125 \\
NiL & 500 & 250 & 500 & 250 \\
PtL & 250 & 250 & 250 & 125 \\
PdL & 125 & 125 & 125 & 62.5 \\
CdL & 250 & 125 & 125 & 125 \\
ZnL & 125 & 125 & 125 & 31.25 \\
Tetracycline & 500 & 250 & 250 & 125 \\
Amikacin & 500 & 500 & 250 & 250 \\
\hline
\end{tabular}

$\mathrm{G}(+)$ denotes Gram positive bacteria and $\mathrm{G}(-)$ denotes Gram negative bacteria.

\section{Materials and Methods}

\subsection{Materials}

All solvents and reagents were obtained from Merck (Darmstadt, Germany) or Sigma Aldrich (St. Louis, MO, USA), and used without further purification. The completion of reactions monitored by TLC (thin layer chromatography) using n-hexane/EtOAC (in a ratio 1:5) as an eluent. Melting points of the compounds were measured by an electro-thermal melting point apparatus and were not corrected. Infrared spectra of the synthesized compounds were recorded with a Shimidzo 300 spectrometer in the region of $4000-400 \mathrm{~cm}^{-1}$ using Potassium bromide pellets. UV-visible spectra were obtained on a Cary 100 spectrophotometer in DMSO solutions. The Mass spectra were performed at $70 \mathrm{eV}$ at $230{ }^{\circ} \mathrm{C}$ with Agilent technologies. The molar conductance of the complexes in DMSO $\left(1 \times 10^{-3} \mathrm{M}\right.$ solution) was carried out at $25^{\circ} \mathrm{C}$ using Oakton EC Tester (Vernon Hills, IL, USA) 11 dual-range, conductivity tester. ${ }^{1} \mathrm{H}-\mathrm{NMR}$ spectra of $\mathrm{NO}_{2}$-ligand were recorded on a Brucker AMX $250 \mathrm{MHz}$ spectrometer (Billerica, MA, USA) in DMSO- $d_{6}$ solvent using tetramethylsilan as an internal reference.

\subsection{Synthesis of the Ligand}

The ligand was prepared according to the previous literature with slight modification [23]. In a $250 \mathrm{~mL}$ clean two-necked round-bottomed flask, containing an ice-cooled mixture of 
N-ethyl-4-nitroaniline $(16.6 \mathrm{~g}, 0.1 \mathrm{~mol})$ in dichloromethane $(100 \mathrm{~mL})$, a solution of phosgene in toluene $(20 \%, 25 \mathrm{~mL}, 0.05 \mathrm{~mol})$ was slowly introduced over a period of $30 \mathrm{~min}$. The mixture was stirred in an ice bath for $3 \mathrm{~h}$, and then left at room temperature overnight. After, it was dried under vacuum ( 2 mbar) at $60{ }^{\circ} \mathrm{C}$, a solid residue was obtained. The obtained solid residue was then dissolved in dichloromethane $(100 \mathrm{~mL})$, and the resulting solution was washed with aq. $\mathrm{HCl}(100 \mathrm{~mL})$, and with water $(3 \times 100 \mathrm{~mL})$, respectively. The organic layer formed was separated and concentrated under vacuum ( $2 \mathrm{mbar}$ ) at $35^{\circ} \mathrm{C}$ to give a thick oil product which was recrystallized via methanol, yielding a colorless product.

(16.4 g, 92\%); M.p. $149-151^{\circ} \mathrm{C}$. Selected IR data $\left(\mathrm{KBr}, \mathrm{cm}^{-1}\right): 3109,2975,1668,1591,1373 .{ }^{1} \mathrm{H}-\mathrm{NMR}$ $\left(250 \mathrm{MHz}, \mathrm{DMSO}-\mathrm{d}_{6}\right): 7.95 \mathrm{ppm}(\mathrm{d}, J=8 \mathrm{~Hz}, 1, \mathrm{Ar}-\mathrm{H}), 7.17 \mathrm{ppm}(\mathrm{d}, J=8 \mathrm{~Hz}, 1, \mathrm{Ar}-\mathrm{H}), 3.74 \mathrm{ppm}$ $\left(\mathrm{d}, J=6.75 \mathrm{~Hz}, 1, \mathrm{CH}_{2}\right), 1.09 \mathrm{ppm}\left(\mathrm{t}, J=12 \mathrm{~Hz}, 2, \mathrm{CH}_{3}\right)$. UV-vis (DMSO): $\lambda \mathrm{Max}=260,340 \mathrm{~nm}$.

\subsection{General Procedure for Preparation of Metal Complexes}

A solution of $(0.2 \mathrm{mmol}) \mathrm{MCl}_{2} \cdot \mathrm{xH}_{2} \mathrm{O}$ in ethanol $(25 \mathrm{~mL})$ was prepared. Then, the solution of ligand $(0.1 \mathrm{mmol})$ in ethanol $(25 \mathrm{~mL})$ was added to it and the resulting mixture was stirred for $1 \mathrm{~h}$ at ambient temperature and allowed to react under reflux for 3-5 h with stirring overnight. After the reaction was completed, the resulting solid was obtained from the solution by filtration. The resulting solid was washed and recrystallized via hot ethanol and finally dried in vacuum desiccator overnight.

\subsubsection{Copper(II) Complex: $\left[\mathrm{Cu}_{2}(\mathrm{~L}) \mathrm{Cl}_{4}\right] \cdot \mathrm{H}_{2} \mathrm{O}$}

Dark green solid; Yield: (75\%); M.p. $240-242{ }^{\circ} \mathrm{C}$. Molar conductance $\Lambda_{\mathrm{m}}\left(\Omega^{-1} \mathrm{~cm}^{2} \mathrm{~mol}^{-1}\right)$ in DMSO: 12. Selected IR data $\left(\mathrm{KBr}, \mathrm{cm}^{-1}\right): 3442,2996,2912,1663,1592,1437,1339,699,669,510$. UV-vis (DMSO): $\lambda_{\text {Max }}=320,490 \mathrm{~nm}$. Mass: $[m / z]^{+}=645$.

\subsubsection{Nickel(II) Complex: $\left[\mathrm{Ni}_{2}(\mathrm{~L}) \mathrm{Cl}_{4}\right] \cdot \mathrm{H}_{2} \mathrm{O}$}

Pale green solid; Yield: (70\%); M.p. $230-232{ }^{\circ} \mathrm{C}$. Molar conductance $\Lambda_{\mathrm{m}}\left(\Omega^{-1} \mathrm{~cm}^{2} \mathrm{~mol}^{-1}\right)$ in DMSO: 10. Selected IR data $\left(\mathrm{KBr}, \mathrm{cm}^{-1}\right)$ : 3432, 2996, 2912, 1661, 1592, 1437, 1339, 701, 669, 600. UV-vis (DMSO): $\lambda_{\operatorname{Max}}=295,410 \mathrm{~nm}$. Mass: $[\mathrm{m} / z]^{+}=636$.

\subsubsection{Cobalt(II) Complex: $\left[\mathrm{Co}_{2}(\mathrm{~L}) \mathrm{Cl}_{4}\right] \cdot \mathrm{H}_{2} \mathrm{O}$}

Pale blue solid; Yield: (83\%); M.p. $242-244{ }^{\circ} \mathrm{C}$. Molar conductance $\Lambda_{\mathrm{m}}\left(\Omega^{-1} \mathrm{~cm}^{2} \mathrm{~mol}^{-1}\right)$ in DMSO: 8. Selected IR data $\left(\mathrm{KBr}, \mathrm{cm}^{-1}\right)$ : 3439, 2996, 2912, 1661, 1515, 1437, 1311, 700, 669, 600. UV-vis (DMSO): $\lambda_{\text {Max }}=3500,600,700 \mathrm{~nm}$. Mass: $[\mathrm{m} / z]^{+}=636$.

\subsubsection{Palladium(II) Complex: $\left[\mathrm{Pd}_{2}(\mathrm{~L}) \mathrm{Cl}_{4}\right] \cdot \mathrm{H}_{2} \mathrm{O}$}

Black solid; Yield: (75\%); M.p. $>300{ }^{\circ} \mathrm{C}$. Molar conductance $\Lambda_{\mathrm{m}}\left(\Omega^{-1} \mathrm{~cm}^{2} \mathrm{~mol}^{-1}\right)$ in DMSO: 12 . Selected IR data $\left(\mathrm{KBr}, \mathrm{cm}^{-1}\right)$ : 3438, 2996, 2912, 1661, 1515, 1437, 1339, 700, 669, 600. UV-vis (DMSO): $\lambda_{\text {Max }}=260,350,510 \mathrm{~nm}$. Mass: $[\mathrm{m} / z]^{+}=730$.

\subsubsection{Platinum(II) Complex: $\left[\mathrm{Pt}_{2}(\mathrm{~L}) \mathrm{Cl}_{4}\right] \cdot \mathrm{H}_{2} \mathrm{O}$}

Dark brown solid; Yield: (50\%); M.p. $>300{ }^{\circ} \mathrm{C}$. Molar conductance $\Lambda_{\mathrm{m}}\left(\Omega^{-1} \mathrm{~cm}^{2} \mathrm{~mol}^{-1}\right)$ in DMSO: 14. Selected IR data $\left(\mathrm{KBr}, \mathrm{cm}^{-1}\right): 3434,2998,2913,1657,1437,1384,702,699$, 550. UV-vis (DMSO): $\lambda_{\text {Max }}=280,350,560 \mathrm{~nm}$. Mass: $[\mathrm{m} / \mathrm{z}]^{+}=910$.

\subsubsection{Zinc(II) Complex: $\left[\mathrm{Zn}_{2}(\mathrm{~L}) \mathrm{Cl}_{4}\right] \cdot \mathrm{H}_{2} \mathrm{O}$}

White solid; Yield: (80\%); M.p. $250-252{ }^{\circ} \mathrm{C}$. Molar conductance $\Lambda_{\mathrm{m}}\left(\Omega^{-1} \mathrm{~cm}^{2} \mathrm{~mol}^{-1}\right)$ in DMSO: 14 . Selected IR data $\left(\mathrm{KBr}, \mathrm{cm}^{-1}\right)$ : 3435, 2996, 2912, 1661, 1437, 1312, 701, 670, 510. UV-vis (DMSO): $\lambda_{\text {Max }}=270,350 \mathrm{~nm}$. Mass: $[\mathrm{m} / \mathrm{z}]^{+}=648$. 


\subsubsection{Cadmium(II) Complex: $\left[\mathrm{Cd}_{2}(\mathrm{~L}) \mathrm{Cl}_{4}\right] \cdot \mathrm{H}_{2} \mathrm{O}$}

Milky solid; Yield: (78\%); M.p. $282-284{ }^{\circ} \mathrm{C}$. Molar conductance $\Lambda_{\mathrm{m}}\left(\Omega^{-1} \mathrm{~cm}^{2} \mathrm{~mol}^{-1}\right)$ in DMSO: 20 IR (KBr, cm ${ }^{-1}$ ): 3435, 2996, 2912, 1661, 1437, 1311, 699, 669, 550. UV-vis (DMSO): $\lambda_{\text {Max }}=245,295 \mathrm{~nm}$. Mass: $[m / z]^{+}=742$.

\subsection{In Vitro Antibacterial Activity}

Antibacterial activities of all synthesized compounds were evaluated against pathogenic strains by applying agar disc diffusion and broth dilution methods [24,25]. The tests were performed using the methodology described in the guidelines of the Clinical and Laboratory Standards Institute (CLSI). The bacterial pathogens used in this study were Bacillus subtilis (ATCC: 6633) and Staphylococcus aureus (ATCC: 6838) as Gram-positive bacteria; and Escherichia coli (ATCC: 25922) and Serratia marcescens (ATCC: 13880) as Gram-negative bacteria. Each of the bacterial strains were cultured onto Muller-Hinton agar (MHA) plate and incubated for $18-24 \mathrm{~h}$ at $35^{\circ} \mathrm{C}$. The turbidity of all microorganisms was adjusted to 0.5 McFarland turbidity standards to obtain a $1.5 \times 10^{8} \mathrm{CFU} / \mathrm{mL}$ suspension.

\subsubsection{Disc Diffusion Method}

All the examined compounds were prepared by dissolving $20 \mathrm{mg}$ of each compound in $1 \mathrm{~mL}$ of DMSO. Thus, DMSO was used as a negative control for all the samples examined. Tetracycline and Amikacin were used as standard drugs. A bacterial culture (which has been adjusted to $0.5 \mathrm{McFarland}$ ) was used to lawn Hinton agar plates using a sterile swab. Paper discs of $8 \mathrm{~mm}$ diameter were impregnated individually with a constant amount $(100 \mu \mathrm{g} / \mathrm{mL})$ of the compounds. Plates were incubated at $37^{\circ} \mathrm{C}$ for $18-24 \mathrm{~h}$ and the antibacterial activity of each test sample was determined by measuring the diameter of zone of inhibition and comparing with standard drug. The antibacterial behavior of each test sample was repeated twice. No inhibition zone was found for DMSO sample.

\subsubsection{Determination of Minimal Inhibitory Concentration (MIC)}

Antibacterial activities of all the compounds and standard drugs were also evaluated using the microdilution method. Each test compound and standard drug individually was prepared in DMSO to obtain $2000 \mu \mathrm{g} / \mathrm{mL}$ concentration (stock solution). The aim of the broth micro-dilution method was the evaluation of the lowest concentration of the examined antibacterial agent to inhibit the visible growth of the microorganism being investigated. Muller-Hinton Broths (MHB) was used as bacterial nutrients. The inoculum size of all strains was adjusted to $1.5 \times 10^{8} \mathrm{CFU} / \mathrm{mL}$ using $0.5 \mathrm{McFarland}$ standard solution for each antibacterial compound and standard drug (tetracycline and amikacin). Thirty-nine tubes of $5 \mathrm{~mL}$ volume were used in 3 rows such that each row contained 13 tubes. Afterwards, $1 \mathrm{~mL}$ of Muller-Hinton Broth (for Row 1 and 2) and $1 \mathrm{~mL}$ of standard drug broth (for row 3 ) were added in Tubes 1-13 in each row. Then, $1 \mathrm{~mL}$ of the antibacterial compound (stock solution) was added to the first tube in each row and mixed. After mixing, $1 \mathrm{~mL}$ of the first tube in each row was serially carried over to the second tube in the same row, mixed and the content of the second tube was transferred to the third tube in each row. This serial dilution was repeated to Tube 12 in each of the rows and $1 \mathrm{~mL}$ of Tube 12 was discarded. Tube 12 had no bacteria and was used as a negative control. Tube 13, without antibacterial agent, was used as a positive control. Thus, the micro-dilution provided antibacterial concentrations of 1000, 500, 250, 125, 62.5, 31.25, 15.62, 7.81, $3.90,1.95,0.975$, and $0.487 \mu \mathrm{g} / \mathrm{mL}$, respectively. Finally, $100 \mu \mathrm{L}$ of bacteria suspension was added to Tubes $1-11$ and 13 in Rows $1-3$ and were incubated for $24 \mathrm{~h}$ at $37^{\circ} \mathrm{C}$. The highest dilution of active sample to inhibit evident growth of the microorganism was expressed as the MIC. 


\subsection{X-Ray Data Collection and Refinement of Crystal Structure of Ligand}

Crystals of 1,3-diethyl-1,3-bis(4-nitrophenyl)urea were grown by slow evaporation from methanol solution. The X-ray diffraction measurement was carried out on STOE IPDS- 2/2T diffractometer with monochromated Mo K $\alpha(\lambda=0.71073 \AA)$ irradiation. The crystal structure of the ligand obtained after one week, was characterized by X-ray crystallography (CCDC code: khc1252h contains the supplementary crystallographic data). The crystal data and structure refinement of the ligand are listed in Table 6. The refinement was carried out using SHELXL. The structure was analysed by direct method. These data can be observed from the Cambridge Crystallographic Data Center via www.ccdc.com.ac.uk/data-request/cif.

Table 6. Crystal structure data of ligand.

\begin{tabular}{|c|c|}
\hline Formula & $\mathrm{C}_{17} \mathrm{H}_{18} \mathrm{~N}_{4} \mathrm{O}_{5}$ \\
\hline Formula weight & 358.35 \\
\hline System & Monoclinic \\
\hline Color/shape & Colorless/plate \\
\hline Space group & $\mathrm{P} 21 / \mathrm{c}$ \\
\hline$a\left(\mathrm{~A}^{\circ}\right)$ & $15.516(3)$ \\
\hline$b\left(A^{\circ}\right)$ & $16.826(3)$ \\
\hline$c\left(\mathrm{~A}^{\circ}\right)$ & $14.975(3)$ \\
\hline$\alpha\left(^{\circ}\right)$ & 90 \\
\hline$\beta\left(^{\circ}\right)$ & - \\
\hline$\gamma\left({ }^{\circ}\right)$ & 90 \\
\hline $\mathrm{T}(\mathrm{k})$ & $298(2)$ \\
\hline$V(\AA-3)$ & $3645.2(14)$ \\
\hline Z & 8 \\
\hline $\operatorname{Dcal}\left(\mathrm{Mg} / \mathrm{m}^{3}\right)$ & 1.306 \\
\hline Absorption coefficient $\left(\mathrm{mm}^{-1}\right)$ & 0.098 \\
\hline Crystal size $(\mathrm{mm})$ & $0.5 \times 0.4 \times 0.25$ \\
\hline$\theta$ Range $\left(^{\circ}\right)$ & 2.42 to 25.00 \\
\hline Reflections collected & 16170 \\
\hline Goodness-of-fit on F2 & 0.893 \\
\hline Data/restraints/parameters & $6398 / 0 / 474$ \\
\hline Final $\mathrm{R}$ indices & $\mathrm{R} 1=0.0677, \mathrm{wR} 2=0.0935$ \\
\hline $\mathrm{R}$ indices (all data) & $\mathrm{R} 1=0.1928, \mathrm{wR} 2=0.1177$ \\
\hline Largest diff. peak and hole (e/ $\AA$-3) & 0.332 and -0.213 \\
\hline
\end{tabular}

\section{Conclusions}

We successfully synthesized novel Cu(II), Ni(II), Co(II), Zn(II), Cd(II), Pd(II) and Pt(II) complexes derived from 1,3-diethyl-1,3-bis(4-nitrophenyl)urea. The structure of the parent ligand was investigated by FTIR, ${ }^{1} \mathrm{H}-\mathrm{NMR}$ and crystallographic spectroscopy. The corresponding metal complexes were characterized using FTIR, UV-Vis and Mass spectroscopy. The FTIR data showed that the ligand bonds to the metal ions via oxygen atom and these data confirmed the formation of nitrito isomer. The measured molar conductivity of the metal complexes was found to be in the range of 8-20 $\mathbf{\Omega}^{-1} \mathrm{~cm}^{2} \mathrm{~mol}^{-1}$ which indicated these complexes were non-electrolytes. By comparing the ligand and its metal complexes, it was found that, in general, metal complexes showed better inhibitory effect and also exhibited much lower MIC values against all the tested bacteria strains. Among these metal complexes, compound with $\mathrm{Zn}$ metal transition showed highest antibacterial activities against both Gram-positive and Gram-negative bacteria strains, when compared to the standard antibacterial drugs. The highest inhibition activity was observed for Zn metal complex against Serratia marcescens bacteria. This suggested that $\mathrm{Zn}$ compound would be better therapeutic drug for antibacterial treatment. 
Supplementary Materials: CCDS khc1252h contains the supplementary crystallographic data for Ligand, and can be obtained free of charge via www.ccdc.com.ac.uk/data-request/cif, or from the Cambridge Crystallographic Data Centre.

Acknowledgments: The authors thank Department of Chemistry, North Tehran Branch, Islamic Azad University, Tehran, Iran for partial financial support of this research.

Author Contributions: Hoda Pasdar conceived and supervised the experiments; Naser Foroughifar designed the experiments and contributed reagents/materials/analysis tools; Bahare Hedayati Saghavaz performed the experiments, wrote the paper and analyzed the data; and Mehran Davallo contributed in proofreading of the entire work and made professional input. All authors read and approved the final manuscript.

Conflicts of Interest: The authors declare no conflict of interest.

\section{References}

1. Pasca, C.; Marghitas, L.; Dezmirean, D.; Bobis, O.; Bonta, V.; Chirila, F.; Matei, L.; Fit, N. Medicinal plants based products tested on pathogens isolated from mastitis milk. Molecules 2017, 22, 1473. [CrossRef] [PubMed]

2. Rios, J.L.; Recio, M.C. Medicinal plants and antimicrobial activity. J. Ethnopharmacol. 2005, 100, 80-84. [CrossRef] [PubMed]

3. Afraid, M.; Foroughifar, N.; Pasdar, H.; Moghanian, H. Facile green one-pot synthesis of novel thiazolo [3,2-a] pyrimidine derivatives using $\mathrm{Fe}_{3} \mathrm{O}_{4} @ \mathrm{~L}$-arginine and their biological investigation as potent antimicrobial agents. Appl. Organometal. Chem. 2016, 31. [CrossRef]

4. Kratky, M.; Mandikova, J.; Trejtnar, F.; Buchta, V.; Stolarikova, J.; Vinsova, J. synthesis and antimicrobial activity of Sulphamethoxazole-based ureas and imidazolidine-2,4,5-triones. Chem. Pap. 2017, 69, 1108-1117. [CrossRef]

5. Supriya, S.; Das, S. Reversible nitro-nitrito inter-conversion in a simple mono-nuclear nickel(II) complex [NiII $\left\{\mathrm{C}_{6} \mathrm{H}_{4}\left(\mathrm{NH}_{2}\right)_{2}\right\}_{2}\left(\mathrm{NO}_{2}\right)_{2}$ ] in the solid state. Inorg. Chem. Commun. 2009, 12, 364-367. [CrossRef]

6. Gonzalez, R.; Barboza, N.; Chiozzone, R.; Kremer, C.; Armentano, D.; Munno, G.; Faus, J. Linkage isomerism in the metal complex hexa(thiocyanato)rhenate(IV): Synthesis and crystal structure of $\left(\mathrm{NBu}_{4}\right)_{2}\left[\operatorname{Re}(\mathrm{NCS})_{6}\right]$ and $\left[\mathrm{Zn}\left(\mathrm{NO}_{3}\right)\left(\mathrm{Me}_{2} \text { phen }\right)_{2}\right]_{2}\left[\operatorname{Re}(\mathrm{NCS})_{5}(\mathrm{SCN})\right]$. Inorg. Chim. Acta 2008, 361, 2715-2720. [CrossRef]

7. Zangl, A.; Klufers, P.; Schaniel, D.; Woike, T. Photoinduced linkage isomerism of binuclear bis(pyrazole-3,5-dicarboxylato)-bridged $\left\{\mathrm{RuNO}^{6}{ }^{6}\right.$ centres. Inorg. Chem. Commun. 2009, 12, 1064-1066. [CrossRef]

8. Chattopadhyay, T.; Ghosh, M.; Majee, A.; Nethaji, M.; Das, D. Linkage isomerism in 4-(2-aminoethyl)morpholine (L) complexes of nickel (II) nitrite: X-ray single crystal structure of trans-[NiL $\left.2\left(\mathrm{NO}_{2}\right)_{2}\right]$. Polyhedron 2005, 24, 1677-1681. [CrossRef]

9. Lee, Y.-L.; Keung, Y.; Sohn, Y.-S. Synthesis, structures, and linkage isomerism of (allylbenzylmalonate)platinum(II) complexes. Inorg. Chim. Acta 1999, 295, 214-221. [CrossRef]

10. Eslami, A.; Hasani, N. Thermoanalytical study of linkage isomerism in coordination compounds part III: A DSC study on the counterion effect on the solid state isomerization of nitro and nitrito linkage isomers of pentaammiecobalt(III) complexes. Thermochim. Acta 2014, 575, 114-121. [CrossRef]

11. Eslami, A. Thermoanalytical study of linkage isomerism in coordination compounds: Part I. Reinvestigation of thermodynamic and thermokinetic of solid state interconversion of nitrito $(\mathrm{ONO})$ and nitro $\left(\mathrm{NO}_{2}\right)$ isomers of pentaaminecobalt(III) chloride by means of DSC. Thermochim. Acta 2004, 409, 189-193. [CrossRef]

12. Camus, A.; Marsich, N.; Lanfredi, A.M.M.; Ugozzoli, F.; Massera, C. Copper(II) nitrito complexes with 2,2'-dipyridylamine. Crystal structures of the [(acetato)(2,2'-dipyridylamine)(nitrito-O,O' $) \operatorname{copper}(\mathrm{II})]$ and $\left[\left(2,2^{\prime}\right.\right.$-dipyridylamine) (nitrito- $\left.O, O^{\prime}\right)(\mu$-nitrito-O)copper(II)]2-2(acetonitrile). Inorg. Chim. Acta 2000, 309, 1-9. [CrossRef]

13. Mautner, F.A.; Vicente, R.; Massoud, S.S. Structure determination of nitrito- and thiocyanato-copper(II) complexes: X-ray structures of $\left[\mathrm{Cu}(\mathrm{Medpt})(\mathrm{ONO})\left(\mathrm{H}_{2} \mathrm{O}\right)\right] \mathrm{ClO}_{4}(1), \quad\left[\mathrm{Cu}(\operatorname{dien})(\mathrm{ONO}) \mathrm{ClO}_{4}\right.$ (2) and $\left[\mathrm{Cu}_{2}(\mathrm{Medpt})_{2}(\mu \mathrm{N}, \mathrm{S}-\mathrm{NCS})_{2}\right]\left(\mathrm{ClO}_{4}\right)_{2}$ (3) $\left(\mathrm{Medpt}=3,3^{\prime}\right.$-diamino- $N$-methyldipropylamine and dien = diethylenetriamine). Polyhedron 2006, 25, 1673-1680. [CrossRef]

14. Byun, J.C.; Lee, W.H.; Han, C.H. Synthesis and characterization of the first tetraazadiphenol macrocyclic dinickel(II) complex containing $\mu\left(O, O^{\prime}\right)$-nitrito-nitro-aqua ligands. Inorg. Chem. Commun. 2006, 9, 563-565. [CrossRef] 
15. Hopa, C.; Kurtaran, R.; Hopa, E.; Cetin, G.; Dundar, E.; Kara, H.; Alkan, M. Nitrito complexes of nickel(II), copper(II) and cobalt(II) with tridentate pyrazole based planar ligand: Structure, spectroscopy, thermal properties and imitative nuclease activity. Inorg. Chim. Acta 2015, 429, 15-21. [CrossRef]

16. Mukhopadhyay, U.; Bernal, I.; Massoud, S.S.; Mautner, F.A. Syntheses, structures and some electrochemistry of $\mathrm{Cu}(\mathrm{II})$ complexes with tris[(2-pyridyl)methyl]amine: $\left[\mathrm{Cu}\left\{\mathrm{N}_{(}\left(\mathrm{CH}_{2}-\mathrm{py}\right)_{3}\right\}\left(\mathrm{N}_{3}\right)\right] \mathrm{ClO}_{4}(\mathrm{I})$, $\left[\mathrm{Cu}\left\{\mathrm{N}\left(\mathrm{CH}_{2}-\mathrm{py}\right)_{3}\right\}(\mathrm{O}-\mathrm{NO})\right] \mathrm{ClO}_{4}$ (II) and $\left[\mathrm{Cu}\left\{\mathrm{N}\left(\mathrm{CH}_{2}-\mathrm{py}\right)_{3}\right\}(\mathrm{NCS})\right] \mathrm{ClO}_{4}$ (III). Inorg. Chim. Acta 2004, 357, 3673-3682. [CrossRef]

17. El-Tabl, A.S.; Shakdofa, M.M.E.; Whaba, M.A. Synthesis, characterization and fungicidal activity of binary and ternary metal(II) complexes derived from 4,4'-((4-nitro-1,2-phenylene) bis(azanylylidene))bis(3-(hydroxyimino)pentan-2-one). Spectrochim. Acta Mol. Biomol. Spectrosc. 2015, 136, 1941-1949. [CrossRef] [PubMed]

18. Green, L.C.; Wagner, D.A.; Glogowski, J.; Skipper, P.L.; Wishnok, J.S.; Tannenbaum, S.R. Analysis of nitrate, nitrite, and $\left[{ }^{15} \mathrm{~N}\right]$ nitrate in biological fluids. Anal. Biochem. 1982, 126, 131-138. [CrossRef]

19. Bredt, D.S.; Glatt, C.E.; Hwang, P.M.; Futuhi, M.; Dawsun, T.M.; Snyder, S.H. Nitric oxide synthase protein and mRNA are discretely localized in neuronal populations of the mammalian CNS together with NADPH diaphorase. Neuron 1991, 7, 615-624. [CrossRef]

20. Colak, A.; Terzi, U.; Col, M.; Karaoglu, S.A.; Karabocek, S.; Kucukgudumlu, A.; Ayaz, F.A. DNA binding, antioxidant and antimicrobial activities of homo- and heteronuclear copper(II) and nickel(II) complexes with new oxime-type ligands. Eur. J. Med. Chem. 2010, 45, 5169-5175. [CrossRef] [PubMed]

21. El-Megharbel, S.M.; Adam, A.M.; Meghdad, A.S.; Refat, M.S. Synthesis and molecular structure of moxifloxacin drug with metal ions as amodel drug against some kinds of bacteria and fungi. Russ. J. Gen. Chem. 2015, 85, 2366-2371. [CrossRef]

22. Patel, M.N.; Pansuriya, P.B.; Parmar, P.A.; Gandhi, D.S. Synthesis, characterization and thermal and biocidal aspects of drug-based metal complexes. Pharm. Chem. J. 2008, 42, 687-692. [CrossRef]

23. Castiglia, A.; El Sehrawi, H.M.; Orbegozo, T.; Spitzner, D.; Claasen, B.; Frey, W.; Kantlehner, J.V. Synthesis and characterization of chiral guanidines and guanidinium salts derived from 1-phenylethylamine. Z. Naturforsch. 2012, 67, 337-346. [CrossRef]

24. Wang, X.; Xie, X.; Cai, Y.; Yang, X.; Li, J.; Li, Y. Design, synthesis, and antibacterial evaluation of some new 2-phenyl-quinoline-4-carboxylic acid derivatives. Molecules 2016, 21, 340. [CrossRef] [PubMed]

25. Gwaram, N.S.; Ali, H.M.; Khaledi, H.; Abdulla, M.A.; Hamid, A.; Hadi, A.; Lin, T.K.; Ching, C.L.; Ooi, C.L. Antibacterial evaluation of some Schiff bases derived from 2-acetylpyridine and their metal complexes. Molecules 2012, 17, 5952-5971. [CrossRef] [PubMed]

Sample Availability: Samples of the compounds 1-25 are available from the authors.

(C) 2017 by the authors. Licensee MDPI, Basel, Switzerland. This article is an open access article distributed under the terms and conditions of the Creative Commons Attribution (CC BY) license (http:/ / creativecommons.org/licenses/by/4.0/). 